\title{
Immigration, Repatriation, and Deportation: The Mexican-Origin Population in the United States, $1920-1950^{1}$
}

Brian Gratton

Arizona State University

Emily Merchant

University of Michigan

Scholars conventionally assert that government authorities forcibly expelled 500,000 persons of Mexican origin from the U.S. in the 1930s, with more than half of those removed U.S. citizens. Estimates using census data indicate substantially lower numbers, limited governmental involvement, fewer citizens, and considerable voluntary departure. Voluntary decisions fit the repatriation strategy that had been common among young Mexican immigrants in the 1920s. Ironically, the 1940s Bracero Program, designed by Mexico and the U.S. to replicate the 1920 s pattern of circular migration, led instead to massive illegal immigration and unprecedented levels of deportation.

\section{INTRODUCTION}

In the wake of the economic collapse of the 1930s, thousands of Mexican immigrants and American-born persons of Mexican origin left the U.S., crossing the border into Mexico. Viewed by scholars as a forced expulsion carried out by federal authorities, the mass movement has become an infamous episode in Mexican-American history and memory. It is as well a

\footnotetext{
${ }^{1}$ This research has been supported in part by Grant Number HD37824-02 from the United States National Institute of Child Health and Human Development and Grant Number R01AG020705 from the United States National Institute on Aging, awarded to Brian Gratton, Principal Investigator. An earlier version was presented at the annual meeting of the Population Association of America in 2011. We thank Edward Telles for his comments on that version, and readers and the editor of the International Migration Review for subsequent reviews.
} 
critical turning point in Mexican-American demography, with a shift toward a native-born, American-oriented ethnic group. Given its critical nature, social scientists should have at hand an interpretation of this event based on empirical evidence.

In 1980, the influential U.S. Commission on Civil Rights report, The Tarnished Golden Door: Civil Rights Issues in Immigration, offered its view: "Federal immigration officials expelled hundreds of thousands of persons of Mexican descent from this country. ...Approximately 500,000 persons were 'repatriated' to Mexico, with more than half of them being United States citizens" (U.S. Commission on Civil, Rights, 1980:10, 44-45). Subsequent estimates have exceeded one million persons forcibly removed and have had demonstrable public effects, including an official apology from the State of California. The bill of apology declared that "In California alone, approximately 400,000 American citizens and legal residents of Mexican ancestry were forced to go to Mexico," and, "In total, it is estimated that two million people of Mexican ancestry were forcibly relocated to Mexico, approximately 1.2 million of whom had been born in the United States..." (California Legislature, 2005-2006).

There is good reason for scholars to be cautious before accepting the three tenets of this conventional tale: That returns were forced, that federal officials carried them out, and that they reached the magnitudes claimed. The evidence for these assertions is often weak or entirely lacking. The Civil Rights Commission, for example, listed sources, but none provided any verifiable evidence for the total number forcibly returned, for federal involvement, or for the extent of citizenship among those repatriated.

In this article, we analyze the data drawn from samples of the U.S. censuses and find that migration of Mexican-origin persons out of the U.S. in the 1930s reached about 350,000, that much of that migration was voluntary, and that federal officials were minimally involved. ${ }^{2}$ These findings correspond with the best evidence from Mexican sources. Moreover, examination of the longer chronicle of migration across the border places this episode in a useful periodization: It followed a decade of heavy

\footnotetext{
${ }^{2}$ Unless otherwise noted, all data used in this article are drawn from samples of the decennial censuses of the U.S. as provided in the Integrated Public Use Microdata Series (IPUMS; Ruggles et al., 2010). We identify persons of Mexican origin using the methods laid out by Gratton and Gutmann (2000), as modified in the HISPAN variable available in IPUMS.
} 
immigration and high levels of voluntary repatriation, and it preceded a decade of rapidly escalating illegal immigration and mass deportation. The 1920s had seen unprecedented levels of Mexican immigration to the U.S., largely made up of young men who sought American wages but intended to repatriate, and did so in numbers greater than those seen in the 1930s. In the 1930s, circular migration collapsed, as many more Mexican immigrants left the U.S. than entered, but a guest worker program in the 1940s revived the pattern. The Mexican and U.S. governments designed the Bracero Program to replicate, under state control, the circular migration of the 1920s; ironically, the guest worker program led instead to illegal immigration and mass deportation at levels beyond the most extreme estimates for the 1930s. In short, rather than an era of unprecedented federal deportation, the 1930s repeated to a great degree the voluntary repatriation of the 1920s. It was the 1940s that witnessed a new regime of expulsion.

\section{PRELUDE: THE 1920s}

Immigration levels from Mexico were quite low before 1900, but rose sharply in the early 20th century, in large part as a consequence of modernization programs carried out under the dictatorship of Porfirio Díaz. As in 19th century European societies, disruption of traditional land and labor systems and improvements in transportation and communication led to rapid increases in internal mobility and to international migration. In the Mexican case, international movement was uniformly north, where similar, closely linked economic development in the American Southwest had created a labor market decidedly short of hands (Cardoso, 1980).

To these propitious conditions was added a greater stimulus as European immigration faltered, first because of World War I and then because of restrictionist legislation in the 1920s that did not apply to the Western Hemisphere. Immigration from Canada and Mexico rose sharply. Indeed, labor shortages in World War I led to the first guest worker program using Mexican workers, and to the repatriation of those workers, carried out by the Mexican government (Reisler, 1976; García y Griego, 1988). Observers in the 1920 s perfectly understood the effect of European restriction. As Census Bureau officials remarked in 1925: "The immigration law has greatly stimulated entrance into the U. S. of Canadians and Mexicans, to whom it does not apply" (Hill, 1926). Figure 1 confirms 
Figure I. Trends in Mexican Immigration, 1880-1930

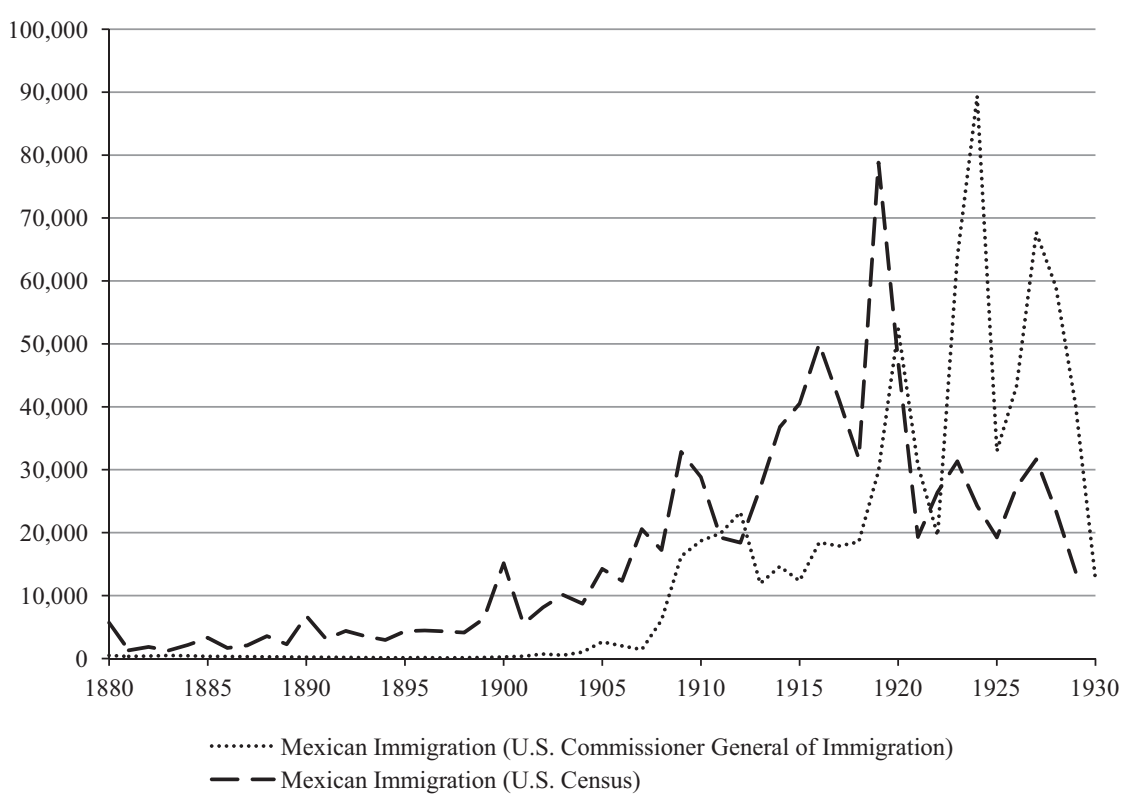

Source: Data from (Ruggles et al., 2010; Carter et al., 2006).

the relationship: Arrivals from Mexico rose steadily after 1900, increased sharply after 1910, and peaked in the mid-1920s.

Most of those who came did not intend to stay. The typical Mexican immigrant in this period was young, male, and solitary. Following a pattern common among European immigrants in this era, young men left in pursuit of high American wages, intending to repatriate. Observers repeatedly remarked on this strategy among Mexicans, for whom costs of repatriation were particularly low (Clark, 1908; Wyman, 1993). Mexican records confirm these observations. Since the early 20th century, the Mexican government had required returning citizens to register at 26 ports of entry. The ports recorded more than 740,000 returns to Mexico between 1920 and 1928; during the four years from 1926 to 1929, at the height of prosperity, 218,000 immigrants voluntarily returned to Mexico (Taylor, 1933-1934; Alanis Enciso, 2007a; the same individual might be counted more than once should he return to the States and repatriate again). García y Griego (1988) estimates that nearly three in every four immigrants returned to Mexico in the 1920s. It was this strategy that led Paul Taylor, a sympathetic observer, to remark that the "extent of the 
repatriation [in the 1930s], large as it is, has been greatly exaggerated in American newspapers and lay opinion"; in his view, the level between 1930 and 1933 "actually turns out to be hardly 50 percent greater than the usual repatriation movement of prosperity" (1933-1934:24).

As a result of circular migration, as late as 1930 , the Mexican immigrant population remained disproportionately young and male. Over 60 percent were aged 20-44, and, in every category until age 60, men outnumbered women. Nonetheless, as was also the case with Europeans, sex ratios began to shift toward parity as women chose to migrate; the arrival of the second generation clearly indicated more permanent settlement. By 1930, persons born in the U.S. but with at least one Mexican-born parent nearly equaled immigrants themselves in number. Table 1 provides estimates of the foreign-born Mexican population, those in the second generation (persons with at least one Mexican-born parent), and those of Mexican origin in subsequent generations for the censuses of 1900 through 1950, as well as the percentage of the Mexican-origin population that was foreign born. Success in the U.S. encouraged not only family formation and greater permanence, but also a wider scope of migration. In the late 1920s, Mexican-origin colonias began to appear in the industrial regions of the Midwest, and immigrants clearly included places outside of the Southwest among their destinations. This broader window of opportunity was quite abruptly shuttered.

\section{THE GREAT DEPRESSION OF THE 1930s AND THE REPATRIATION CAMPAIGNS}

By the mid-1920s, as their presence became more evident, hostility toward Mexicans rose, taking on a racial tone (Hoffman, 1976). The

TABLE 1

Mexican Origin Persons in the U.S. by Generation, 1900-1950

\begin{tabular}{llcccc}
\hline \hline Census & $\begin{array}{c}\text { Born in } \\
\text { Mexico }\end{array}$ & $\begin{array}{c}\text { Second } \\
\text { Generation }\end{array}$ & $\begin{array}{c}\text { Subsequent } \\
\text { Generations }\end{array}$ & $\begin{array}{c}\text { Total of } \\
\text { Mexican Origin }\end{array}$ & $\begin{array}{c}\text { Percent Foreign } \\
\text { Born }(\%)\end{array}$ \\
\hline 1900 & 99,286 & 116,324 & 171,299 & 386,909 & 26 \\
1910 & 237,196 & 160,874 & 211,485 & 609,555 & 39 \\
1920 & 499,547 & 249,755 & 235,553 & 984,855 & 51 \\
1930 & 649,207 & 614,988 & 427,561 & $1,691,756$ & 38 \\
1940 & 387,600 & 685,200 & 518,900 & $1,591,700$ & 24 \\
1950 & 456,390 & 914,430 & 906,840 & $2,277,660$ & 20 \\
\hline
\end{tabular}

${ }^{1}$ Born in the U.S., with at least one parent born in Mexico.

${ }^{2}$ Born in the U.S. and both parents born in the U.S., but identified as Mexican-origin in IPUMS HISPAN variable. Source: Data from (Ruggles et al., 2010). 
depression provoked still greater antagonism. Antipathy toward immigrants erupted in many countries, as witnessed in the violent expulsion of the Chinese from northwestern Mexico in 1931 and 1932 (New York Times, 1932; Hu-DeHart, 1982; Lim, 2010). As the global economic crisis deepened, most nations, including Mexico, severely limited or barred new arrivals (New York Times, 1930; Hatton and Williamson, 2005). Americans perceived the most recent arrivals, Mexicans, as especially culpable for competing for jobs and relying on welfare, and they became targets of focused antagonism (Fox, 2010; 2012). Repatriation campaigns urging Mexicans to go back to Mexico appeared in a variety of locales, and they were the only immigrant-origin group so targeted.

Repatriation and deportation are not equivalent: People repatriate, governments deport. As a decision made by an individual to return to a home country, repatriation implies no legal procedures at the federal or local level. As job prospects fell in the early 1930s, voluntary return to Mexico fit the conventional circular strategy of the 1920s. Historians and social scientists nonetheless emphasize the "coercion" that prompted migration to Mexico in this period (Balderrama and Rodríguez, 2006:305), asserting that those who went to Mexico were "forcibly

TABLE 2

Estimates of Repatriation and Migration to Mexico in the Scholarly Literature

\begin{tabular}{lc}
\hline \hline Sources & Estimate \\
\hline Balderrama and Rodríguez (2006) & $1,000,000$ or more \\
Kropp (2006) & \\
Zolberg (2006) & \\
Lim (2010) & \\
California Legislature (2005-2006) & 500,000 \\
Haney López (2006) & \\
U. S. Commission on Civil, Rights (1980) & \\
Guérin-Gonzales (1994) & $400,000-499,999$ \\
Durand, Massey, and Zenteno (2001) & \\
Deutsch (1987) & \\
Ngai (1999) & \\
Alba and Nee (2003) & \\
Perlmann (2005) & \\
Ruiz (2006) & \\
Katz, Stern, and Fader (2007) & \\
Massey (2006) & \\
Hoffman (1974) & \\
Alanis Enciso (2007b) & \\
Hahamovitch (2003) & 331,717 \\
Carreras de Velasco (1974) &
\end{tabular}


deported" (Massey, 2006) and that governmental authorities carried out a "forced deportation" (Perlmann, 2005:27). The common claim is that about one half million persons were forcibly expelled, though higher estimates regularly appear, as do a few more cautious appraisals [see Gutiérrez (1995) and Monroy (1999)]. Table 2 classifies the range of estimates in the scholarly literature.

Scholarship asserting high estimates and coercion often refers to two books, Balderrama and Rodríguez, Decade of Betrayal (2006) and Guérin-Gonzales, Mexican Workers and American Dreams (1994). The more careful account in Hoffman, Unwanted Mexican Americans in the Great Depression (1974), is less commonly cited. Balderrama and Rodríguez state that, "Taking the conservative middle ground, it is reasonable to estimate that the total number of repatriates was one million," and that "approximately 60 percent of those summarily expelled were children who had been born in the United States and were legally American citizens" (2006:151, 330). They provide no clear, direct evidence for their estimates, citing a variety of Mexican newspaper articles and government records from both countries, disparaging the latter. Guérin-Gonzales does not carry out any independent calculations, citing Mexican government data discovered by Hoffman (1974), and she includes 1929 in the data she cites. She asserts that there was a "forced expulsion of half a million immigrants" and "Americans of Mexican descent," and these persons were "targets of one of the largest mass-removal operations ever sanctioned by the United States government" (Guérin-Gonzales, 1994:1,8).

Accounts such as these tend to ignore the well-established migration strategies pursued by Mexicans (and other immigrants); they rarely attend closely to the vigorous activity of the Mexican government in encouraging repatriation or to the historical context of strong linkages to Mexico among immigrants in the U.S. In contrast, Hoffman (1974) provides an empirically based account using superior Mexican government data, gives attention to both voluntary and coercive repatriation, and explores the large role of the Mexican government in facilitating returns to the home country. As Hoffman details, officials in Los Angeles County and other southern California jurisdictions stand out for their promotion of repatriation to reduce welfare costs, and for the close cooperation in that endeavor they received from the Mexican government. Sánchez concludes that Los Angeles Mexican "consul Rafael de la Colina jumped at the chance to help facilitate the repatriation of Mexican nationals and their often American-born children" (1993:123). In a system used in other locales, those 
desiring to repatriate signed up in advance; when sufficient numbers had done so, a train departure date was set. The county paid for the trip and for provisions; a county or Mexican consulate official accompanied passengers to the border and through customs to transportation provided by the Mexican government. While federal immigration officers were not directly involved in repatriation, they conducted aggressive deportation programs in 1931 that at times coincided with local offers of repatriation assistance; there is evidence of cooperation between federal and local authorities for a brief period in such deportation sweeps (Hoffman, 1973; Kang, 2005; Fox, 2012). U.S. newspaper accounts cite unemployment as the chief motivation among repatriates but also report that aggressive deportation and rising anti-Mexican sentiment contributed to the decision to leave (New York Times, 1931a).

Detailed accounts of repatriation campaigns in Los Angeles, East Chicago and Gary, Indiana and Houston indicate that welfare officials and citizens' groups first offered assistance to those wishing to go and then became more insistent that Mexicans leave. Although there is little hard evidence of forced removal of legal residents, the change in tone is evident. In Simon's (1974) close account of East Chicago, the "voluntary and humanitarian" characteristics of 1930 and 1931 gave way in 1932 to harsher demands for Mexicans to leave, voiced by more established immigrant-origin groups and the American Legion, which argued that Mexicans took jobs and strained meager welfare resources (14). Simon finds that most repatriates said they left voluntarily, yet concludes that "some coercion" was evident, with Mexican residents recalling threats of loss of welfare benefits, and of feeling "pressure" to leave (17). Simon also describes the sudden end of repatriation efforts after the 1932 campaign, due to the lack of funds, decline of popular sentiment for the campaigns, and the new flow of federal welfare. Examining repatriation in Texas, McKay (2012) concludes that most early returns were voluntary, enthusiastically encouraged by the Mexican government. Subsequent deportation raids and more coercive repatriation campaigns, especially in urban areas, then emerged.

Fox (2012) argues that immigration officials collaborated with local welfare agencies in the Southwest to facilitate aggressive deportation and repatriation campaigns. She faults in particular social workers in this region, whose racist view of Mexicans as public charges incapable of assimilation led to lies about rights to return, threats to cut off welfare, or bribery. She concludes that such tactics affected an unstated proportion of 
the perhaps 30,000-40,000 repatriates aided by relief agencies between 1930 and 1935 (2012:187).

Violations of rights certainly occurred, because, unless illegally resident, Mexican immigrants were under no requirement to leave the U.S. That said, in many cities, such as Chicago, St. Paul, and San Antonio, and in states including Arizona, Utah, Ohio, and New Mexico, repatriation programs were small, purely voluntary, or never appeared at all (New York Times, 1934; Betten and Mohl, 1973; Simon, 1974; Kerr, 1976; Blackwelder, 1984; Deutsch, 1987; García, 1996; Valdés, 1991, 2000; Iber, 2000; Marin, 2005; Meeks, 2007; McKay, 2012).

Moreover, repatriation had, as we have seen, been a dominant voluntary strategy among Mexican immigrants, one encouraged by the Mexican government as a response to discontent in that country over the exodus of young men and women, the loss of these sons and daughters seen as an economic catastrophe and a symbol of national failure. In 1929, Armando Vargas de la Maza complained that Mexico had in the past given to the U.S. the riches of its territory, but now provided "el oro de nuestra sangre" ("the treasure of our blood"; Carreras de Velasco, 1974:43). Political factions in Mexico regularly advanced demands that emigrants be brought back to the homeland. Although usually longer on rhetoric than resources, the Mexican state sought, through the 1940s, the re-incorporation of emigrants into its territorial boundaries. In 1907, Porfirio Díaz assisted Mexican immigrants seeking to return from the U.S.; after the Revolution, from 1920 to 1922, Presidents Adolfo de la Huerta and Alvaro Obregón financed repatriation (Cardoso, 1977; Aguila, 2007).

In the 1930s, in addition to official Mexican government assistance, a quasi-public organization in Mexico, the "Comité de Repatriación," collected relief funds for repatriates, intending eventually to establish agricultural colonies (Carreras de Velasco, 1974; Cardoso, 1977; Aguila, 2007; Alanis Enciso, 2011). Private organizations in the U.S. promoted returns, largely through Catholic charitable societies and Mexican-American mutualistas, or benevolent aid societies, such as the Comisiones Honoríficas Mexicanos and the Brigadas de la Cruz Azul, and these were often organized with direct assistance from consular offices of the Mexican government (Aguila, 2004). While residing in Detroit, the Mexican muralist Diego Rivera established the "Liga de Obreros y Campesinos" to aid in the repatriation of Mexicans in Michigan to "colonization projects in Mexico" (Valdés, 2000:95). As in other cities, Chicago Spanish language newspapers reported the Mexican government's subvention of railroad fare 
for travel within Mexico as well as assistance for transportation within the U.S.; they also conveyed the local Mexican consul's active encouragement of repatriation (Arredondo, 2008).

Given the difficulty of finding work in the U.S., free transportation and promises of Mexican government assistance appealed to those who retained strong ties to Mexico. Looking back on the experience, the Midwestern repatriate Pilar Goméz Norrick remarked that "repatriation was voluntary.... We were happy to leave" (Betten and Mohl, 1973:370). Repatriates retained rights to return to the United States and many may have intended to do so. Mexican authorities and journalists criticized repatriates' practice of taking assistance to come to Mexico and then returning to the U.S. "several times." As one critic remarked, "They arrived in Mexico with optimism, happy to return to Mexico, but with the intention of returning to the United States" (Carreras de Velasco, 1974:135). An observer in 1933 in Los Angeles noted the "holiday spirit that seemed to pervade the deportees.... Those to whom I spoke expected to return the next spring and were glad of the opportunity to visit relatives in Mexico" (Hoffman, 1974:127).

Given the anecdotal nature of evidence of repatriation efforts, Hoffman's great contribution was the discovery and use of data drawn from the Departamento de Migración de México or Mexican Migration Service (MMS), which was charged with recording emigrants' return to Mexico. Repatriates (and, in the 1930s, their American-born children) registered at the Mexican ports of entry. These ports lay on the most convenient, efficient, and safe routes. Although some did not use these entry points, the Mexican historian of repatriation Alanis Enciso finds no evidence in Mexican sources of large numbers crossing at other sites (2007a, 2008). Registration imposed no cost and provided specific benefits; indeed, during the 1930s crisis, "registrations for entering [Mexico] were quite abundant" due to repatriates' "interest in enjoying exemptions" from taxes on goods brought back from the U.S., free transportation to residences in Mexico, and, for some, land promised in repatriation colonies (Carreras de Velasco, 1974:131). Using the MMS repatriation figures, Hoffman concludes that the total migration into Mexico - from purely voluntary to deportation - for the period 1929-1935 was "in excess of 415,000" (Hoffman, 1974:126).

Mexican scholarship has followed a similarly judicious utilization of port of entry data. In Los Mexicanos que devolvió la crisis 1929-1932, Carreras de Velasco (1974) argues that repatriations before 1930 were part 
of the conventional immigrant strategy and that there was little return after 1933. Using entry records from the Mexican government's National Department of Statistics and the Department of Foreign Affairs, she concludes that 311,717 Mexican-origin persons came from the U.S. from 1930 through 1933. Using primarily the same sources, Alanis Enciso (2007a, b) provides the most recent analysis. Like Carreras de Velasco, he classifies 1929 as part of customary repatriation strategies and agrees generally with her estimate through 1933 . He then extends the period examined to 1940, arguing that hostility to Mexican immigrants continued across the decade. He estimates that there were 425,000 repatriates (including immigrants' native-born children) and deportees between 1930 and 1940.

\section{DEPORTATION, REPATRIATION, AND MIGRATION IN THE $1930 \mathrm{~s}$}

In the crisis of the 1930s, reasons for migration to Mexico ranged from (1) the conventional immigrant return strategy, to (2) special financial assistance from American or Mexican government agencies and charities, to (3) the threats embedded in public campaigns in certain locales, and to (4) extraordinary levels of deportation. In contrast to the first category, returns motivated by financial assistance, coercive campaigns, or extraordinary deportation can be seen as marking the special case of Mexicans, that is, levels of migration that exceed what might be expected of an immigrant-origin group for whom no repatriation campaigns occurred.

Given their openly coercive nature, and concrete numbers available, deportations deserve first attention. As immigration officers noted, land borders facilitated illegal entry. Although Canadians and Mexicans were not subject to restrictive quotas, migrants who circumvented official entry points avoided visa fees and literacy tests. Deportations "under warrant" occurred after formal hearings determined that the alien was subject to removal; the return was carried out at government expense. Threatened with such proceedings, immigrants could choose to leave the country, at their own expense, without voiding their rights to return, through voluntary deportation. Annual deportation figures are found in the reports of the U.S. Bureau of Immigration, and, beginning in 1933, the Immigration and Naturalization Service (INS). These show that, by the mid1920s, Mexicans and Canadians comprised nearly half of all formal 
deportees, generally expelled for not having acquired a visa (United States Department of Labor, 1919-1940). ${ }^{3}$ Between 1919 and 1929, federal authorities deported about 22,000 Mexicans and 16,000 Canadians under warrant. Although figures for voluntary deportations are available only in 1930 and from 1933 forward, these suggest that voluntary deportations reached about the same level as formal deportations for these two groups in the late 1920s. Deportation rose in the 1930s, and the share comprised by Mexicans and Canadians increased to three-fourths of all deportees. For the 11 years from 1930 to 1940, 62,608 Mexicans and 21,546 Canadians were deported under warrant; more complete data in this decade lead to an estimate of an additional 67,000 Mexicans and 30,000 Canadians voluntarily returning after arraignment.

Formal deportations of Mexicans occurred at a particularly dramatic rate from 1930 through 1933, as part of an explicit Hoover administration policy announced in his State of the Union Address in 1930 (Hoover, 1930; Hull, 1931). After 1933, when New Deal officials took charge, both formal and voluntary deportation fell for all immigrants, but especially for Mexicans. ${ }^{4}$ How much did deportations in the Hoover period exceed expected levels? We calculate the missing figures for voluntary deportation in 1931 and 1932 as the mean of the 1930 and 1933 reported numbers; we calculate them in the late 1920s as equal to formal deportations. Under these conditions, formal and voluntary deportations for Mexicans from 1925 to 1929 reached about 6,200 per year, and, from 1934 to 1939, approximately 8,900 annually. The mean of these two rates, 7,550, is the expected annual rate for 1930 to 1933, and yields an expected 30,200 total deportations. Formal deportations and actual and estimated voluntary deportations sum to 63,874 for this 4-year period. We therefore estimate that the Hoover period witnessed an excess deportation of 33,674 Mexicans.

\footnotetext{
${ }^{3}$ The reports covered the fiscal year, which ended on June 30 of the report year. The Annual Report was usually published in the year of the report but occasionally in the next year. The reports did not initially include persons apprehended near the border and immediately returned.

${ }^{4}$ New Deal officials dealt with much lower immigration but they also instituted more lenient policies, especially for well-settled, if technically illegal, immigrants (see U. S. Department of Labor, 1934, 1935). Kang (2005) argues vigorously for this transition and, in sharp contrast to Fox (2012), argues that immigration officials were reluctant even before the New Deal to participate in repatriation campaigns or in expensive deportation programs. See also Moloney (2012) and Ngai (2003).
} 
The other components in migration to Mexico have heretofore been observable only in the Mexican port of entry data. However, the samples we use of the U.S. censuses of 1930 and 1940 (Ruggles et al., 2010) supply representative data for the U.S. population at those dates and provide a new method for estimating total out migration to Mexico during the 1930s. Comparing the number of Mexican-born individuals and U.S.born individuals of Mexican parenthood in 1930 and 1940, adjusting for expected mortality, provides an estimate of total repatriation (including within it deportation) across the decade. Census data preclude two types of error inherent in port of entry records: They count those who did not return through the official ports, and they do not double- or triple-count those who went to Mexico, emigrated to the U.S. again and migrated to Mexico again.

They do introduce other possibilities for error. They count new immigrants from Mexico as if they had been in the U.S. in 1930 and treat persons who left and then returned to the U.S. as if they had never crossed the border. ${ }^{5}$ Given the low levels of immigration during the depression, these errors may be small. Federal entry records show that only 35,022 persons entered the U.S. legally from Mexico between 1930 and 1940 (Carter et al., 2006). IPUMS data indicate that 11,429 persons born in Mexico but less than 10 years of age were living in the U.S. in 1940. Federal immigration reports and deportation records do show that many Mexicans crossed the border illegally, even during the Depression years, often being apprehended near the border and returned immediately. While the level of new immigration to the U.S. cannot be measured accurately, it could lead to underestimates of repatriation. If so, such ease of re-entry would certainly undermine the view of most accounts that pressures continued through the 1930s and that repatriation was a form of permanent expulsion.

The 1930 IPUMS provides a robust estimation of the first and second generations through a 1-in-20 national random sample for each gen-

\footnotetext{
${ }^{5}$ Errors of underenumeration and classification exist in all censuses and in the samples taken of them. Hacker (2013) estimates undercounts between 5 and 6 percent between 1900-1930 for native-born whites but acknowledges these would be higher for the foreign born. For discussion of such errors for Mexicans in the 1930 census, see Bloch (1929) and García y Griego (1988). Errors may be largely the same across censuses, making comparative assessments reliable if not perfectly accurate. As we note, in both 1940 and 1950, information about the birthplace of parents was moved to the sample line, considerably reducing confidence in estimates.
} 
eration. Indeed the sample is the only way to identify the second generation in that year, as the census did not publish data on native-born persons with at least one parent born in Mexico. The 1940 IPUMS provides a 1-in-100 national random sample for the first generation, but census officials moved the inquiry regarding birthplace of parents to a questionnaire asked of only 1 in 20 persons. The IPUMS sampling procedure ensured that each household selected had a member who answered the supplementary questionnaire, but its sampling frame meant that parental birthplace information fell to 1 in every 350 persons. Hence, caution must be exercised with estimates of second-generation characteristics.

Following Carreras de Velasco and Alanis, we take 1930 as the first year of extraordinarily high levels of return. For immigrants, we estimate net repatriation, migration, and deportation by subtracting the number of Mexican-born persons 10 years and older in the 1940 census from the number in 1930, less those expected to have died during the decade [Le Bras (2008) describes a similar approach to net migration]. We apply Hill's (1936) and Greville's (1947) age- and sex-specific single-year survival rates to the age-sex structure of the Mexican-born U.S. population in 1930. Age- and sex-specific 10-year survival rates for 1930-1940 were derived by averaging the $1(\mathrm{x})$ column in life tables separately for white males and females (in the U.S. in 1929-1931 from Hill and 1939-1941 from Greville) and calculated as $1(\mathrm{x}) / \mathrm{l}(\mathrm{x}-10)$. Given the lower socioeconomic status of Mexicans, this produces a conservative estimate of mortality in that population. We base survival estimates on 1930 IPUMS data, classified by sex and 1-year age groups. Total survivorship is the sum over all ages of the product of the number in each age and sex group and the corresponding survival rate. The calculation yields the expected number of immigrants in the U.S. in 1940 had none returned to Mexico, and no new immigrants arrived. The difference between those expected to be in the U.S. in 1940 and those actually present (aged 10 and over) provides the measure of net migration to Mexico.

In 1930, there were 649,207 persons of Mexican birth in the U.S. Given the age and sex distribution of the foreign-born Mexican population in 1930, 54,815 would have died in the 10-year interval (a conservative estimate given low socioeconomic status in this population). Corrected for mortality, the expected population aged 10 and over in 1940 is 594,392 . The actual population at least 10 years of age in 1940 was 374,660. Implied net emigration across the decade therefore equaled 219,732 persons, a repatriation rate of 33.8 percent of the immigrant 


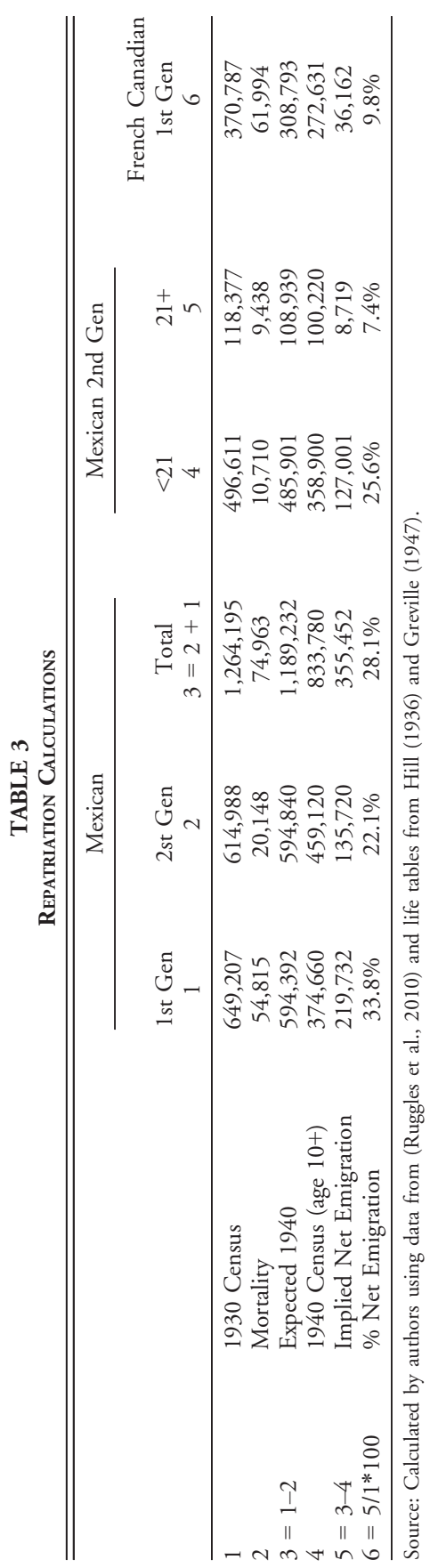


population resident in 1930. (These and subsequent repatriation calculations are provided in Table 3). Deportees, approximately 130,000 across the decade, made up a very large proportion of the total, although caution must be exercised since voluntary deportees could return legally. Given the rates seen in the 1920s and late 1930s, most deportations would have occurred under normal conditions, only 34,000 lying beyond the expected level.

Persons born in the U.S. to Mexican parents also left for Mexico. IPUMS data reveal 614,988 persons of American birth with at least one Mexican-born parent in 1930. In this much younger second generation, 20,148 would have died (again, a conservative estimate), and the expected number of second-generation Mexican Americans 10 years of age or over would have been 594,840 . The actual number of this age in the 1940 census was $459,120 .^{6}$ Thus, the implied number of net emigrants was 135,720, yielding a rate of 22.1 percent in the second generation (Table 3). Combining the first and second generations yields an implied net emigration to Mexico of 355,452 between 1930 and 1940, circa 28 percent of the first- and second-generation population in 1930. This figure is quite close to the estimates of repatriation made from Mexican government data and 29 percent lower than the common estimate of 500,000.

The proportion of emigrants who were citizens is also lower than the 60 percent usually estimated. Second-generation, native-born citizens constituted 38 percent of the total flow into Mexico $(135,720 / 355,452)$. These were predominantly children emigrating with their repatriating parents - 93 percent were under 21 years of age. [The implied rate of net emigration for those 21 and over was 7 percent, compared with over 25 percent for those under 21 (Table 3)]. In addition, some first-generation Mexicans had become citizens. The 1930 census sample indicates that 10.1 percent were citizens or had taken out naturalization papers, making up 65,570 of the first-generation population. Having strengthened their ties to the U.S., such persons were unlikely to leave and could not be deported. If the same proportion went to Mexico as among the second generation who were 21 and over (7 percent), then 4,200 naturalized citizens might have returned to their land of birth. Adding these to the sec-

\footnotetext{
${ }^{6}$ This figure depends on sample line data in 1940, at a much reduced sampling ratio. Published data, using all sample line entries, indicated 459,180 in the second generation aged ten and over, a comparable figure. Such concordance is not always the case with other groups, including French Canadians.
} 
ond-generation migrants implies that American citizens made up approximately 40 percent of the net emigration to Mexico.

IPUMS data also permit an experimental, comparative approach to a much less tractable question: What proportion of migrants went to Mexico because of hostile repatriation campaigns, or special financial inducements, or extraordinary levels of deportation, rather than as part of the conventional voluntary strategy? While deportation is coercive, the level of compulsion and inducement is difficult to measure in repatriation campaigns and assistance programs. Carreras de Velasco captures the conundrum well: "the return to Mexico covered the whole gamut between a voluntary return and a forced one and since repatriation was of such magnitude and frequency in the period, it was confusing even in the feelings of the repatriate himself, knowing himself to be deported and asking for his repatriation at the same time" (1974:57).

One approach to the problem compares Mexican out migration to that of an immigrant-origin group not affected by the special factors that influenced persons of Mexican origin. No such comparison can be exact, making results speculative. The exercise nonetheless demonstrates that repatriation and emigration were strategies that immigrant-origin populations commonly used. Immigration restriction legislation in the early 1920s had forced most Europeans to abandon circular migration and choose where to reside; those who gave up residence in the U.S. could not return (Wyman, 1993; see also U.S. Department of Labor, 1928). The result was low rates of repatriation in the 1930s for these groups: Poles, for example, show a net emigration rate of 7.3 percent. The 1920s laws did not, however, restrict the entry and reentry of Mexicans and Canadians. While not as young, single, male, and recently arrived as Mexicans, French Canadians provide a useful comparison group. Their immigration had begun in the 19th century, but the restriction of European arrivals had also sparked renewed emigration from Quebec in the 1920s. French Canadians shared signal characteristics with Mexicans, the most vital an irredentist geography, with a home country across a land border, facilitating circular migration. In its 1910-1911 report, the Dillingham Commission found that French Canadians had the second highest rate of return among immigrants. Like Mexicans, they had low socioeconomic status, a closely held language, and strong Catholic faith. Moreover, in Quebecois culture and politics, one finds the same lament for lost sons and daughters and the same repeated, if largely rhetorical, government plans to facilitate their return (Time, 1923; Theriault, 1980; U.S. Congress, Immigration Commission, 1910-1911; Gerstle, 1989; Roby, 
2000; Ramirez, 2001; Bélanger and Bélanger, 2000; MacKinnon and Parent, 2005).

In the early phases of their immigration French Canadians had been targets of considerable xenophobia; in 1881, the Chief of the Massachusetts Bureau of Statistics of Labor, Carroll Wright, described them as the "Chinese of the Eastern States" (1881:469). By the 1930s, these negative reactions had subsided; they were well established in New England communities. They did not suffer the racialization evident for Mexicans, and only isolated incidents of nativist reaction to them occurred during the Depression. Roby (2000) refers to reports from Manchester, New Hampshire, that Quebec agents had repatriated several thousand persons in 1930 and 1931; there is evidence of a passing interest in their repatriation from U.S. immigration officials (New York Times, 1931b,c). Certainly, no sustained pressure came to bear on them to leave the U.S., nor extensive governmental or private assistance to aid them in doing so; deportations did not rise to extraordinary levels during the Hoover administration. French-Canadian repatriation thus provides a comparative example of expected exits from the U.S. in hard times, without explicit repatriation campaigns.

The 1930 census reported 370,787 persons of French-Canadian origin. Age- and sex-specific mortality would have reduced this population by 61,994 over 10 years, leaving an expected population 10 years of age and older in 1940 of 308,793 . The actual population of that age was 272,631 , indicating an implied net emigration of 36,162 persons, or 9.8 percent of the resident 1930 population. If this were the expected rate of return during hard times for irredentist populations, the excess proportion for Mexican immigrants would be 24 percent (33.8 percent minus 9.8 percent). Using this proportion, repatriation among Mexicans beyond that which was expected was 24 percent of the 649,207 population in 1930, or 155,810 persons. This calculation ignores differences in age and sex ratios that might affect propensity to repatriate. For example, the median age of the French-Canadian population was 45, versus 32 for Mexicans. We can correct for differences in age and sex ratios by applying the implied repatriation rates in the age/sex categories of French Canadians to the same categories for Mexicans. ${ }^{7}$ Using French-Canadian rates, we

\footnotetext{
${ }^{7}$ The youngest age group of French Canadians (age 0-14 in 1930) experienced net immigration, that is, more came into the U.S. than left; we assume that all implied emigration among Mexicans in that age group was excess.
} 


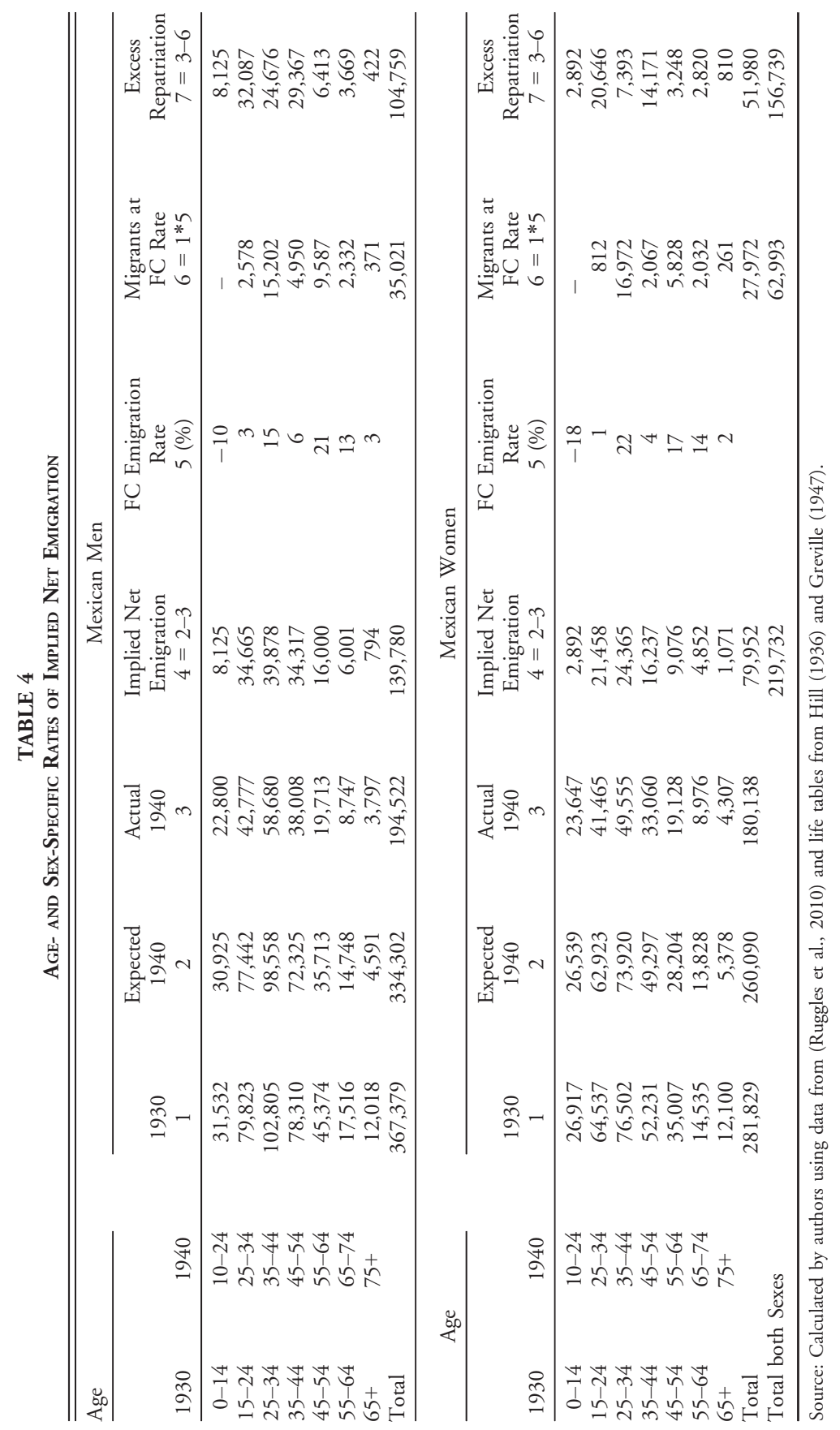


would expect 62,993 Mexican repatriates. This suggests an excess repatriation of 156,739 persons, modestly higher than the first estimate. Table 4 provides these calculations, as well as implied net emigration by sex and 10-year age groups.

Repatriation beyond that expected in the second generation requires a different approach, as the great majority of emigrants crossed the border because of parental decisions rather than their own. We assume most children emigrated with their mothers, and that these Mexican women were between 15 and 44 years of age. If Mexican women had the same agespecific rates of implied net emigration as French-Canadian women between 1930 and 1940 (shown in Table 4), their net repatriation would have been 19,851 . Instead, it was 42,210 , suggesting that 53 percent $[(42,210-$ $19,851) / 42,210]$ of this migration was beyond what would be expected. That percentage implies an excess net emigration in the second generation of 67,311 persons under 21 years of age $(0.53 \times 127,001-$ from Table 3). As it is likely that the repatriation rate of mothers was lower than that for women without children (also included in this repatriate age group), the estimate of 67,311 is biased upward. Summing the generations, repatriation beyond that expected in hard times may have reached 225,000 persons of Mexican origin.

Total movement to Mexico in the 1930s was then circa 355,000 (Table 3). Perhaps 40 percent were American citizens, nearly all children returning with their parents. Within this number, migration to Mexico beyond what might be expected for an immigrant-origin group in the depression may have reached a total of about 225,000. Federal involvement consisted largely of an aggressive deportation policy in the period 1930-1933 that added about 34,000 persons to the number expected under conventional rates of deportation. The overall estimate is congruent with Mexican port of entry data for the critical period of the early 1930s, as reported by Hoffman and Mexican scholars. While the estimates of excess repatriation are speculative, the common assertion that half a million persons were forced to leave the U.S. does not appear plausible. Vibrant circular migration in the 1920s, the strong adherence of many Mexican immigrants to their home country, and the out migration of other immigrant-origin groups, suggests that many persons of Mexican origin would have migrated as economic conditions worsened in the U.S., absent repatriation campaigns. 


\section{EPILOGUE: THE 1940S}

Repatriation, migration, deportation, and mortality reduced the Mexicanorigin population across the 1930s; few immigrants came from Mexico during that decade. The foreign-born share of the population declined, a fate shared by all immigrant-origin groups. Despite a return to prosperity in the 1940s, legal immigration did not increase; official records counted only 60,000 arrivals from Mexico (Carter et al., 2006) and census samples indicate about 69,000 new entrants. As Table 1 shows, the foreign born, once more than half of the Mexican-origin population, had fallen to a one-fifth share by 1950 .

Some in the second generation had also left for Mexico in the 1930 s, but the great majority stayed in the U.S., and 232,600 were born in that decade. These births heralded the still more rapid expansion of the Mexican-origin community in the 1940s. By 1950, the population (including all generations) exceeded 2.2 million persons, a level one-third larger than in 1930. This increasingly native-born community turned toward the U.S. rather than Mexico (Sánchez, 1993; Gutiérrez, 1995).

It appeared, then, that immigration had left center stage after 1930. In fact, Mexican immigrants became a more powerful and contentious force than ever. In August, 1942, the Mexican and U.S. governments signed an "Agreement Respecting the Temporary Migration of Mexican Agricultural Workers" (1942). This "Bracero" guest worker program was powerfully influenced by the history of Mexican immigration and repatriation in the 1920s and 1930s. ${ }^{8}$ Mexican authorities were keenly aware of their citizens' hostility to emigration, as well as the opposition of employers, the Catholic Church, and some unions. Nonetheless, increasingly cordial economic and diplomatic relations with the U.S. made cooperation possible. The Mexican government also feared that intense labor demand in the north would provoke illegal emigration in any case. Abuses in the brief World War I guest worker experiment, racism, discrimination against Mexican immigrants in the U.S. during the 1920s, and, above all,

\footnotetext{
${ }^{8} \mathrm{~A}$ voluminous literature attends to the Bracero Program. Except where interpretation is in conflict, we report without citation the consensus in the empirical examination of both U.S. and Mexican sources in the following: Rasmussen, 1951; Scruggs, 1960, 1961, 1963, 1988; Kiser, 1974; Lessard, 1984; García y Griego, 1988; Jungmeyer, 1988; Grove, 1996; Kang, 2005; Snodgrass, 2011. See also Galarza, 1964; Craig, 1971, and Calavita, 1992.
} 
the costly repatriation of citizens in the 1930s led Mexican authorities to demand specific criteria in the initial agreement. Workers were to have written contracts, fixed and reasonable wages, and guaranteed, financed repatriation at the end of tenure; moreover, the U.S. and Mexican governments, not private employers, would manage recruitment and contractual agreements and would ensure non-discriminatory treatment.

For their part, U.S. officials also regretted the damage done to relations with Mexico in the 1930s. The American public was hostile to any renewal of immigration and settlement, particularly by Mexicans, and officials faced opposition from unions and the working class, who feared Mexican competition with native-born American workers. Mexican-American organizations were also antagonistic, because they saw a flood of Mexican guest workers as competitors and a threat to their status in the U.S. (Valdés, 1991; Gutiérrez, 1995; Kaplowitz, 2005). A state-managed program that forestalled illegal immigration, avoided permanent settlement, and provided a financed, orderly repatriation fit the historical lessons learned in the 1920s and 1930s. Agreement on these stipulations led the governments to establish the guest worker program, and more than 400,000 bracero contracts were issued, primarily in agricultural work, between 1942 and 1950 .

In this impressive attempt to impose state control over migration, Mexico and the U.S. sanctioned and facilitated the circular strategy that Mexicans had employed in the 1920s and in early 1930s. Young male workers, and males only, could journey to the U.S. with the requirement that they return to Mexico at the end of their contracts. Such managed migration, both Mexico and the U.S. reasoned, would restrain the abuses that had emerged from unregulated labor markets, mute public disapproval, and prohibit the permanent settlement that neither country favored. ${ }^{9}$

A pressing demand for labor in a state gearing up for war opened the door to a radical departure from restrictionist policy; that same demand provided the Mexican government the bargaining power necessary to insist on strict criteria. Nonetheless, the Bracero Program, which lasted until 1964, represented an astonishing policy achievement by com-

\footnotetext{
${ }^{9}$ Hahamovitch (2003) argues that host states use compulsory repatriation to placate citizens hostile to foreign settlement; in this case, although U.S. authorities held this view, the Mexican government was the more insistent state, and Mexican workers had long practiced repatriation on their own initiative.
} 
mercial agricultural interests in the U.S., one similar in magnitude to that they attained in the exclusion of Mexicans from the quota acts of the 1920s. ${ }^{10}$ The breadth of their accomplishment was not fully realized until after the war. Not only did the "emergency" program not end in 1945, but the guest worker system promoted an outcome it was intended to avoid, illegal immigration. The undocumented population in the U.S., almost uniformly from Mexico, rose in concert with the program's expansion, a result seen in guest worker experiments in other countries (Tomasi, 1986; Massey and Liang, 1989; Hahamovitch, 2003). American commercial farmers, unhappy with government constraints, encouraged illegal immigration. Mexican workers were eager to comply: Some swamped recruitment centers in central Mexico while others simply travelled north, crowding into border towns and crossing the line without papers. Braceros began to overstay or break their contracts or, having become familiar with the U.S. and with job sites, crossed the border without official permission.

By the mid-1940s, apprehensions of Mexicans illegally present in the U.S. exceeded 60,000 per year, and in 1950, amounted to 458,000 individuals (Carter et al., 2006). Such apprehensions often led to deportation, but deportations were increasingly of the voluntary kind, in which individuals did not void their right to return to the U.S. ${ }^{11}$ While formal deportations remained relatively stable, voluntary departures reached unprecedented levels, rising from 93,330 in the period from 1931 to 1940 to $1,470,925$ between 1941 and 1950 , nearly all of these occurring after 1944 and nearly all by Mexicans. As the INS Annual Report noted in 1947, "Ninety-four percent of the voluntary departures were from the three southwestern border districts" (Immigration and Naturalization Service, 1941-1959; 1947: 24). Given that Mexicans constituted the largest group in formal departures as well (a total of 110,849 between 1941 and

\footnotetext{
${ }^{10}$ Calavita (1992) contends that internal government agencies "first and foremost" (4) served their own needs. Such an approach hardly explains the previous achievements of Southwestern agricultural interests in immigration policy, nor her own evidence of INS submission to demands made by large growers (34ff). She acknowledges that the INS "used its considerable administrative ingenuity ... to mold and shape the program to maximize its utility to bracero employers"(3). Kang (2005) provides a useful reconsideration.

${ }^{11}$ The INS was transferred to the Department of Justice in 1941, as World War II began. During the war years, annual reports were brief, inconsistently released, and often not formally published. Summary figures for the decade can be found in the 1957 annual report (Immigration and Naturalization Service, 1941-1959).
} 
1950), federal authorities deported more than 1.3 million Mexican nationals between 1941 and 1950, a figure three times the level of all returns in the 1930s and ten times the number of deportations during that decade.

Undocumented immigration undermined state authority and quickly transformed the program into a vehicle still more attractive to employers. It removed from the deck Mexico's bargaining card, which had been control over the number of workers the U.S. could receive. After the war, Mexico, unwilling or unable to restrain emigration, compromised on its once strict criteria, as the flood of illegal immigrants with no contracts or repatriation clauses seemed the worse alternative. As early as 1943, Mexican officials were aware of the considerable flow of American dollars into Mexico because of bracero earnings, a sum augmented by remittances from illegal workers (Lessard, 1984; García y Griego, 1988). In the U.S., the power of Southwestern agricultural interests in Congress was manifest. American officials showed themselves unwilling to penalize employers who hired illegal workers or to enforce non-discrimination clauses. They actively sought the "direct employer-to-worker [contractual] arrangement" (García y Griego, 1988:148) that growers wanted. Deportees were often quickly recycled into new contracts, re-legalizing their presence, as the Mexican government preferred. Indeed, the INS, at times resistant to agribusiness demands, more often facilitated illegal crossings to benefit growers, and the Service admitted that it avoided deportation sweeps during the periods of intense work demands on farms.

There is scarce evidence that Mexican braceros "were disciplined by the threat of deportation" (Hahamovitch, 2003:83); their practice of skipping contracts and extensive illegal immigration attest to considerable freedom of movement. INS raids and apprehensions regularly angered growers, but the Service often used voluntary deportation to clear the market of unemployed illegal workers and legalization to resupply it. Mass voluntary deportation revealed the transformation of a governmentally managed program into one in which employers enjoyed both a government-aided labor supply and an illegal labor supply, and Mexican workers were eager to sustain both (Snodgrass, 2011). Although state policy had intended to blunt their effects, the labor market forces that propelled Mexican migration in the 1920s and early 1930s had returned with still greater energy, animated by that formal policy. Mass arrival and mass exit continued. The state now had a role, but it was to aid and abet those 
forces: It authorized contracts for entry, and it carried out a sustained, difficult, and expensive process of mass deportation for exit.

\title{
CONCLUSION
}

In 1951, President Truman wrote to his counterpart in Mexico, Miguel Alemán Valdés (1951):

\begin{abstract}
I am anxious to see progress made toward improving working conditions and living standards for our own citizens and for the contract workers from Mexico who are employed on our farms... But if these things are to occur the governments of the United States and Mexico must take steps to shut off the stream of Mexican citizens immigrating illegally into the United States.
\end{abstract}

Truman reacted to the consequences of a long-established strategy among Mexican immigrants, one that was to persist into the 21 st century. The volatile, transnational, and voluntary circuit of immigration and repatriation among young Mexican men in the 1920s had itself repeated a circular migration common among European immigrants in the early 20th century. As in those other migrations, permanent settlement appeared. But, among those of Mexican origin, these characteristics gave way abruptly in the early 1930s to the levels of deportation higher than customary, to mass repatriation, and to emigration to Mexico by some in the second generation. While thousands moved southward, across the border, the scholarly literature on the "repatriation" crisis has exaggerated the number of persons involved and underestimated the initiative these migrants exercised. Migration reduced the Mexican-origin population in the U.S. during the 1930s, but only briefly interrupted its long-term growth. More than 70 percent of persons of Mexican origin in 1930 remained in the U.S. and, by 1950 , the population was larger than it had ever been, mostly native born, and increasingly vocal in demanding its rightful place in the U.S.

Even in the prosperous 1940s, legal immigration was low. In its place, the Bracero Program endeavored to recreate, under state management, the earlier pattern of circular migration. Ironically, it provoked that which it was designed to prevent, illegal immigration. This unintended consequence led to massive deportations of undocumented Mexican nationals, well beyond the levels seen in the 1930s. Young Mexican men 
showed themselves once again more than willing to venture north, legally or illegally, fully expecting to return to Mexico.

The magnitude of the state's forcible expulsion of Mexicans in the 1930s has been overestimated. Deportation in the 1940s was extraordinary, yet has attracted less attention. Neither the 1930s repatriation nor the deportations of the 1940 s demonstrate state control over movement across the border. As in the past, U.S. employers and Mexican workers made the crucial decisions, with the state at best a junior partner. This increasingly chaotic migration presented to President Truman, as it would to future American and Mexican policymakers, the conundrum of reliance and reluctance embedded in the long history of migration between Mexico and the U.S., a puzzle surpassingly difficult to solve.

\section{REFERENCES}

"Agreement Respecting the Temporary Migration of Mexican Agricultural Workers" 194256 Stat. 1759, Executive Agreement Series 278.

Aguila, J. R.

2004 "Ayuda Mutua Mexicana: el Origen de las Comisiones Honoríficas y las Brigadas de la Cruz Azul." In Labor Consular Mexicana en Estados Unidos Siglos XIX y XX: Cinco Ensayos Históricos. Ed. F. S. Alanis Enciso. Naucalpan, MX: Senado de la República. Pp. 95-120.

2007 "Mexican/United States Immigration Policy Prior to the Great Depression." Diplomatic History 31(2):207-225.

Alanis Enciso, F. S.

2007a “¿Cuántos fueron? La repatriación de mexicanos en los Estados Unidos durante la Gran Depresión: Una interpretación cuantitativa, 1930-1934.” Aztlán: A Journal of Chicano Studies 32(2):65-91.

2007b Que se queden allá. El gobierno de México y la repatriación de mexicanos de Estados Unidos, 1934-1940. Tijuana: El Colegio de la Frontera Norte/El Colegio de San Luis.

2008 Personal Communication to Brian Gratton, email, June 24.

2011 "The Repatriation of Mexicans from the United States and Mexican Nationalism, 1929-1940." In Beyond la Frontera: The History of Mexico-United States Migration. Ed. M. Overmyer-Velazquez. New York: Oxford University Press. Pp. 51-78.

Alba, R. D. and Nee, V.

2003 Remaking the American Mainstream: Assimilation and Contemporary Immigration. Cambridge: Harvard University Press.

Arredondo, G. F.

2008 Mexican Chicago: Race, Identity, and Nation, 1916-1939. Champaign: University of Illinois Press. 
Balderrama, F. E. and R. Rodríguez

2006 Decade of Betrayal: Mexican Repatriation in the 1930s. Albuquerque: University of New Mexico Press.

Bélanger, D. and C. Bélanger

2000 "French Canadian Emigration to the United States, 1840-1930."In Readings in Quebec History. <http://faculty.marianopolis.edu/c.belanger/quebechistory/readings/ leaving.htm>. Accessed on July 25, 2012.

Betten, N. and R. A. Mohl

1973 "From Discrimination to Repatriation: Mexican Life in Gary, Indiana, During the Great Depression.” Pacific Historical Review 42(3):370-388.

Blackwelder, J. K.

1984 Women of the Depression: Caste and Culture in San Antonio, 1929-1939. College Station: Texas A\&M University Press.

Bloch, L.

1929 "Facts About Mexican Immigration Before and Since the Quota Restriction Laws." Journal of the American Statistical Association 24(165):50-60.

Calavita, K.

1992 Inside the State: The Bracero Program, Immigration, and the INS. New York: Routledge. California Legislature

2005-2006 S.B. No. 670, Apology Act for the 1930s Mexican Repatriation Program

Cardoso, L. A.

1977 “La repatriación de braceros en la época de Obregón 1920-1923." Historia Mexicana 26(4):576-595.

1980 Mexican Emigration to the United States, 1897-1931. Tucson: University of Arizona Press.

Carreras de Velasco, M.

1974 Los mexicanos que devolvió la crisis 1929-1932. Tlatelolco: Secretaría de Relaciones Exteriores.

Carter, S. B., S. S. Gartner, M. R. Haines, A. L. Olmstead, R. Sutch and G. Wright (eds)

2006 Historical Statistics of the United States: Millennial Edition On Line. New York: Cambridge University Press. <http://hsus.cambridge.org.ezproxy1.lib.asu.edu/HSUSWeb/HSUSEntryServlet>. Accessed on February 5, 2013.

Clark, V. S.

1908 "Mexican Labor in the United States." Bulletin of the [United States] Bureau of Labor 78(17):466-522.

Craig, R. B.

1971 The Bracero Program: Interest Groups and Foreign Policy. Austin: University of Texas Press.

Deutsch, S.

1987 No Separate Refuge: Culture, Class, and Gender on an Anglo-Hispanic Frontier in the American Southwest, 1880-1940. New York: Oxford University Press.

Durand, J., D. S. Massey and R. M. Zenteno

2001 "Mexican Immigration to the United States: Continuities and Changes." Latin American Research Review 36(1):107-127.

Fox, C.

2010 "Three Worlds of Relief: Race, Immigration, and Public and Private Social Welfare Spending in American Cities." American Journal of Sociology 116(2):453-502. 
2012 Three Worlds of Relief: Race, Immigration, and the American Welfare State from the Progressive Era to the New Deal. Princeton: Princeton University Press.

Galarza, E.

1964 Merchants of Labor: The Mexican Bracero Story; an Account of the Managed Migration of Mexican Farm Workers in California, 1942-1960. Charlotte: McNally and Loftin.

García, J. R.

1996 Mexicans in the Midwest, 1900-1932. Tucson: University of Arizona Press.

García y Griego, L. M.

1988 "The Bracero Policy Experiment: U.S.-Mexican Responses to Mexican Labor Migration, 1942-1955." PhD diss., University of California-Los Angeles.

Gerstle, G.

1989 Working-Class Americanism: The Politics of Labor in a Textile City, 1914-1960. New York: Cambridge University Press.

Gratton, B. and M. P. Gutmann

2000 "Hispanics in the United States, 1850-1990: Estimates of Population Size and National Origin.” Historical Methods 33(3):137-153.

Greville, T. N. E.

1947 United States Life Tables and Actuarial Tables 1939-1941. Washington, DC: United States Government Printing Office.

Grove, W. A.

1996 "The Mexican Farm Labor Program, 1942-1964: Government-Administered Labor Market Insurance for Farmers." Agricultural History 70(2):302-320.

Guérin-Gonzales, C.

1994 Mexican Workers and American Dreams: Immigration, Repatriation, and California Farm Labor, 1900-1939. New Brunswick: Rutgers University Press.

Gutiérrez, D. G.

1995 Walls and Mirrors: Mexican Americans, Mexican Immigrants, and the Politics of Ethnicity. Berkeley: University of California Press.

Hacker, J. D.

2013 "New Estimates of Census Coverage in the United States, 1880-1930." Social Science History 17(1):71-101.

Hahamovitch, C.

2003 "Creating Perfect Immigrants: Guestworkers of the World in Historical Perspective 1." Labor History 44(1):69-94.

Haney López, I.

2006 White By Law: The Legal Construction of Race. New York: New York University Press.

Hatton, T. J. and J. G. Williamson

2005 Global Migration and the World Economy: Two Centuries of Policy and Performance. Cambridge: The MIT Press.

Hill, J. A.

1926 "Correspondence of Joseph A. Hill, 1911-32." Administrative Records of the Office of the Bureau of the Census. RG29: February 5.

1936 United States Life Tables. Washington, DC: United States Government Printing Office.

Hoffman, A.

1973 "Stimulus to Repatriation: The 1931 Federal Deportation Drive and the Los Angeles Mexican Community.” Pacific Historical Review 42(2):205-219. 
1974 Unwanted Mexican Americans in the Great Depression: Repatriation Pressures, 19291939. Tucson: University of Arizona Press.

1976 "An Unusual Monument: Paul S. Taylor's Mexican Labor in the United States Monograph Series.” Pacific Historical Review 45(2):255-270.

Hoover, $\mathrm{H}$.

1930 "Annual Message to the Congress on the State of the Union." The American Presidency Project. <http://www.presidency.ucsb.edu/ws/index.php?pid=22458>. Accessed on January 30, 2013.

Hu-DeHart, E.

1982 "Racism and Anti-Chinese Persecution in Sonora, Mexico, 1876-1932." Amerasia Journal 9(2):1-28.

Hull, H. E.

1931 "The Tide of Migration Turns Away From America's Shores." New York Times. Aug. 9.

Iber, J.

2000 Hispanics in the Mormon Zion, 1912-1999. College Station: Texas A\&M University Press.

Immigration and Naturalization Service

1941-1959 Annual Reports. Washington, DC: U.S. Department of Justice. Accessible at HathiTrust Digital Library. <http://catalog.hathitrust.org/Record/

Jungmeyer, R. L. 000546059>. Accessed on February 12, 2013.

1988 "The Bracero Program, 1942-1951: Mexican Contract Labor in the United States." $\mathrm{PhD}$ dissertation, University of Missouri-Columbia.

Kang, S. D.

2005 "The Legal Construction of the Borderlands: The INS, Immigration Law, and Immigrant Rights in the U.S.-Mexico Border, 1917-1954“. PhD diss., University of California-Berkeley.

Kaplowitz, C. A.

2005 LULAC, Mexican Americans, and National Policy. College Station: Texas A\&M University Press.

Katz, M. B., M. J. Stern and J. J. Fader

2007 "The Mexican Immigration Debate: The View from History." Social Science History 31(2):157-189.

Kerr, L. A. N.

1976 "The Chicano Experience in Chicago: 1920-1970." PhD diss., University of Illinois-Chicago Circle.

Kiser, G. C.

1974 "The Bracero Program: A Case Study of its Development, Termination, and Political Aftermath." PhD dissertation, University of Massachusetts.

Kropp, P. S.

2006 California Vieja: Culture and Memory in a Modern American Place. Berkeley: University of California Press.

Le Bras, $\mathrm{H}$.

2008 The Nature of Demography. Princeton: Princeton University Press.

Lessard, D. R.

1984 "Agrarianism and Nationalism: Mexico and the Bracero Program, 1942-1947." PhD diss., Tulane University. 
Lim, J.

2010 "Chinos and Paisanos: Chinese Mexican Relations in the Borderlands." Pacific Historical Review 79(1):50-85.

MacKinnon, M., and D. Parent

2005 "Resisting the Melting Pot: The Long Term Impact of Maintaining Identity for Franco-Americans in New England." Cahiers de recherché, CIRPEE Working Paper no. 5-17. <http://papers.ssrn.com/sol3/papers.cfm?abstract_id=739627>. Accessed on July 25, 2012.

Marin, C. N.

2005 "Always a Struggle: Mexican Americans in Miami, Arizona, 1909-51.” PhD diss., Arizona State University.

Massey, D. S.

2006 "Borderland Madness." Chronicle of Higher Education 52(43):B11.

and Z. Liang

1989 "The Long-term Consequences of a Temporary Worker Program: The U.S. Bracero Experience." Population Research and Policy Review 8(3):199-226.

McKay, R. R.

2012 "Mexican Americans and Repatriation." Handbook of Texas Online. <http://www. tshaonline.org/handbook/online/articles/pqmyk>. Accessed on July 25, 2012.

Meeks, E. V.

2007 Border Citizens: The Making of Indians, Mexicans, and Anglos in Arizona. Austin: University of Texas Press.

Moloney, D. M.

2012 National Insecurities: Immigrants and U.S. Deportation Policy Since 1882. Chapel Hill: University of North Carolina Press.

Monroy, D.

1999 Rebirth: Mexican Los Angeles From the Great Migration to the Great Depression. Berkeley: University of California Press.

New York Times.

1930 "Canada Bars Immigrants." August 16.

1931a “35,000 Mexicans Leave California: Migration Expected To Reach 75,000.” April 12.

1931b “Expects Deportation of French Canadians.” April 16.

1931c “Repatriating Canadians.” April 25.

1932 "Chinese Again Flee Agitation in Mexico." August 6.

1934 “300 Mexicans to leave Ohio.” March 20.

Ngai, M.

1999 "The Architecture of Race in American Immigration Law: A Reexamination of the Immigration Act of 1924." Journal of American History 86(1):67-92.

2003 "The Strange Career of the Illegal Alien: Immigration Restriction and Deportation Policy in the United States, 1921-1965." Law and History Review 21(1):69-107.

Perlmann, J.

2005 Italians Then, Mexicans Now: Immigrant Origins and Second-Generation Progress, 1890 to 2000. New York: Russell Sage Foundation. 
Ramirez, B.

2001 Crossing the 49th Parallel: Migration from Canada to the United States, 1900-1930. Ithaca: Cornell University Press.

Rasmussen, W. D.

1951 A History of the Emergency Farm Labor Supply Program, 1943-47. Washington, Reisler, M.

D.C.: U.S. Department of Agriculture Bureau of Agricultural Economics.

1976 By the Sweat of their Brow: Mexican Immigrant Labor in the United States, 1900-

Roby, Y. 1940. Westport, CT: Greenwood Press.

2000 Les Franco-Américains de a la Nouvelle-Angleterre: Rêves et réalités. Sillery: Septentrion.

Ruggles, S., T. Alexander, K. Genadek, R. Goeken, M. B. Schroeder and M. Sobek.

2010 Integrated Public Use Microdata Series: Version 5.0 [IPUMS] [Machine-readable database]. <http://usa.ipums.org/usa/cite.shtml>. Accessed on June 15, 2013.

Ruiz, V. I.

2006 "Nuestra América: Latino History as United States History." Journal of American History 93(3):655-728.

Sánchez, G. J.

1993 Becoming Mexican American: Ethnicity, Culture, and Identity in Chicano Los Angeles, 1900-1945. New York: Oxford University Press.

Scruggs, O. M.

1960 "Evolution of the Mexican Farm Labor Agreement of 1942." Agricultural History 34(3):140-149.

1961 “The United States, Mexico, and the Wetbacks, 1942-1947.” Pacific Historical Review 30(2):149-164.

1963 “Texas and the Bracero Program, 1942-1947." Pacific Historical Review 32(3):251264.

1988 Braceros, "Wetbacks," and the Farm Labor Problem: Mexican Agricultural Labor in the United States, 1942-1954. New York: Garland Publishing.

Simon, D. T.

1974 "Mexican repatriation in East Chicago, Indiana." Journal of Ethnic Studies 2(2):1123.

Snodgrass, $\mathrm{M}$.

2011 "The Bracero Program, 1942-1964," In Beyond la Frontera: The History of MexicoUnited States Migration. Ed. M. Overmyer-Velazquez. New York: Oxford University Press. Pp. 79-102.

Taylor, P. S.

1933-1934 Mexican Labor in the United States, Migration Statistics IV. Berkeley: Univer-

Theriault, G. F. sity of California Press.

1980 The Franco-Americans in a New England Community: An Experiment in Survival. New York: Arno Press.

Time

1923 “In Rhode Island.” September 10. 
Tomasi, S. M. (ed).

1986 "Temporary Worker Programs: Mechanisms, Conditions, Consequences." Special Issue, International Migration Review 20(4).

Truman, H. S.

1951 Letter to Miguel Alemán. Migratory Labor Folder 17: Mexican Labor. Independence, MO: Truman Papers. Truman Library. July 14.

United States Commission on Civil Rights

1980 The Tarnished Golden Door: Civil Rights Issues in Immigration. Washington, DC: United States Government Printing Office.

United States Congress, Immigration Commission

1910-1911 Abstracts of Reports of the Immigration Commission: With Conclusions and Recommendations, and Views of Minority. 2vol., Washington, DC: United States Government Printing Office. I, 61 Cong., 3 sess.

United States Department of Labor

1919-1940 Annual Reports. Washington, DC: United States Government Printing Office.

Valdés, D. N.

1991 Al Norte: Agricultural Workers in the Great Lakes Region, 1917-1970. Austin: University of Texas Press.

2000 Barrios Norteños: St. Paul and Midwestern Mexican Communities in the Twentieth Century. Austin: University of Texas Press.

Wright, C. D.

1881 "Part III. Uniform Hours of Labor." Twelfth Annual Report of the [Massachusetts] Bureau of Statistics of Labor. Boston: Rand, Avery, \& Co.

Wyman, M.

1993 Round-Trip to America: The Immigrants Return to Europe, 1880-1930. Ithaca: Cornell University Press.

Zolberg, A. R.

2006 A Nation by Design: Immigration Policy in the Fashioning of America. New York: Russell Sage Foundation and Boston, Harvard University Press. 